\title{
Stakeholder Participation in Project Planning: Prerequisite to Effective Completion of Urban Road Transport Infrastructure Projects in Kenya
}

\author{
Johnson Matu*, Dorothy Kyalo*, J. Mbugua, Angeline Mulwa \\ Open Distance and eLearning Campus, University of Nairobi, Nairobi, Kenya \\ Email: ^matupec@gmail.com, ^ndunge.kyalo@yahoo.com
}

How to cite this paper: Matu, J., Kyalo, D., Mbugua, J. and Mulwa, A. (2020) Stakeholder Participation in Project Planning: Prerequisite to Effective Completion of Urban Road Transport Infrastructure Projects in Kenya. Journal of Building Construction and Planning Research, 8, 73-91.

https://doi.org/10.4236/jbcprt.2020.81006

Received: November 4, 2019

Accepted: March 28, 2020

Published: March 31, 2020

Copyright $\odot 2020$ by author(s) and Scientific Research Publishing Inc. This work is licensed under the Creative Commons Attribution International License (CC BY 4.0).

http://creativecommons.org/licenses/by/4.0/

\begin{abstract}
Stakeholder involvement in the project planning process should include a variety of actors with different roles and responsibilities at the planning phase of the project life cycle. Failure to adequately plan greatly reduces the project's chances of successfully accomplishing its goals. The objective of this study was to determine the influence of stakeholder participation in project planning on the completion of urban road transport-infrastructure projects in Kenya. Pragmatic research paradigm was utilized for this study to facilitate mixed research methods. The study adopted descriptive survey and correlational research design. The target population was 1593. A sample size of 309 respondents was drawn utilizing purposive and simple random sampling procedures. A five point Likert type scale questionnaire was used to collect quantitative data while interview guides were used to collect qualitative data. The study found that stakeholder participation in project planning had a positive and significant influence on the completion of urban road transport infrastructure projects in Kenya $\left(\mathrm{r}=0.838, \mathrm{R}^{2}=0.703, \mathrm{~F}(4,209)=123.43, \mathrm{p}<\right.$ $0.001<0.05) . R^{2}=0.703$ indicating that stakeholder participation in project planning explains $70.3 \%$ of the variations in the completion of urban road transport infrastructure projects in Kenya. The study concluded that stakeholder participation in project planning significantly influences completion of urban road transport-infrastructure projects in Kenya. The study recommends the need to increase training and awareness on participation in project planning. The study also recommends the need to develop a guiding policy document detailing the importance of stakeholder participation in road construction life cycle in order to curb any future misgivings in implementation of these important socio-economic projects.
\end{abstract}




\section{Keywords}

Stakeholder Participation, Project Planning, Budgeting, Scope Planning, Resource Planning

\section{Introduction}

Road transport infrastructure network is often seen as the arteries through which a country's economy survives, since roads are expected to link economic entities such as markets, employees to workplaces, students to learning institutions, and other socio-economic activities. Yet much of the developing world, Africa in particular, lacks adequate transportation infrastructure [1]. The modern stakeholder participation concept began in the 1930s as corporations debated responsibilities on this subject [2]. The newfangled priority on stakeholder engagement developed together with the quality movement that is centered on the concept that all individuals and entities involved in the development and consumption of products or services are responsible for quality assurance. In view of Gardiner [3] the two movements complement each other. He also embraces the opinion that risk and profit should not be prioritized ahead of the process of stakeholder engagement and management.

Public participation is embraced by several countries with the objective of enhancing, promoting and facilitating public participation in governance processes. According to Khan, Skibnieski and Cable [4], globally, project stakeholders are now considered as one of the major critical success factors on every given complex construction infrastructural projects. For instance, the Republic of Kenya has constitutional provisions for public participation as provided for by the Constitution of Kenya (2010). Additionally, in accordance with the County Governments Act 2012, and section 126 of the Public Finance Management Act (2012), the County Governments in Kenya are mandated to involve the public and other stakeholders in development projects through collection of their views and involvement in the decision making process. Kenya's National Assembly passed Public Participation Act, 2018, to reinforce the need for stakeholder participation it states that "the object of this Act is to enhance, promote and facilitate public participation in governance processes" [5].

The project planning phase begins after the initiation or conception phase and it is the stage where the entire project is planned. The planning process which requires full participation of stakeholders includes scope definition, the redefinition of project objectives and developing the course of action required to attain those objectives. According to Williams [6], planning primarily establishes a set of important directions to inform the project team exactly the course of action(s), and time for the actions to be implemented, required resources for achieving the project's deliverables successfully, and finally a schedule for availing the resources. Cheng, Shimiao, and Danfeng [7] affirm this point in stating 
that in project planning stage, activities are defined, expected end products are outlined and particularly the ways activities are to be accomplished are known. In addition to these, each major task is defined, time estimate and resources required are established, and a framework for management review and control provided for. This demonstrates the relationship between stakeholder participation and project planning which informs the predictor variable of this study, thus stated, stakeholder participation in project planning and design.

Numerous studies on the subject of stakeholder participation and especially in project planning have been undertaken worldwide albeit different types of projects [2] [8] [9] [10] [11] [12]. Most projects are in construction and less on road transport infrastructure; however, this topic seems not to go away easily since the uptake of stakeholder participation in road construction projects is still very low and poor despite its crucial role in delivery of projects. For instance, a number of issues affecting project planning such as budgeting, resource planning project scheduling, project scoping, have been established in both global sphere and Kenyan context indicating that stakeholder participation needs to be scaled up during project planning phase [8]-[16]. A further observed is that unless all parties to the planning process have a clear understanding of what it is the project is expected to deliver, the planning process may not be successful [17].

Different authors have come up with various definitions of who a stakeholder is. For instance, Freeman [18] sees stakeholders as "a group or individual that affects or is affected by an organization reaching its objectives". Notably, several studies [18] [19] [20] [21] adopt this definition. On the other hand, stakeholders are described as individuals or groups that habitually offer the desired resources and have the capacity to control the interaction and resource flows in the network [8]. This study adopted the definition by Freeman [18] where a stakeholder is described as a group or an individual who affects or is affected by an organization's objectives. This choice is informed by Mitchell, Agle and Wood [22] who suggest that if stakeholders perceive they are being treated unfairly (or are not involved), they may compromise the success of an organization or project and thus the need for managers give attention and priority to stakeholder involvement.

Stakeholders play various roles in the project development stages; Mitchell, Agle and Wood, [22] present a methodology that aims to demonstrate in what way the attributes of power, legitimacy and urgency explain the degree of importance managers accord stakeholders' requests [23]. Furthermore, Nguyen, and Menzies, [24] argue that an institution's social performance can be assessed more successfully through its dealings with its stakeholders. All these studies point to the importance of stakeholder involvement for project of organizations' success.

This study therefore, sought to examine the influence of stakeholder participation in project planning phase of urban road transport-infrastructure projects 
in the Republic of Kenya. The stakeholders in this study as already defined are group or individual who affects or is affected by the urban road contraction projects in Kenya. They include the public road users' groups referred to as "Matatu Savings and Credit Co-operatives (SACCOs)"-"matatu" is public transport vehicle in Kenya-the Kenya Power Company whose power lines are affected, the water and sewerage companies whose drainage and piping is affected, land commission officials who regulate land use and Project Affected Persons (PAPs).

\section{Literature Review}

Notably, project success has been described differently by authors [1] [4] [7] [11] [13]. The performance criteria of Urban Road Transport Infrastructure Projects, is assessed based the parameters of: completion within time, cost, quality standards and stakeholder satisfaction. The need to address the challenge of project performance has been voiced over time in the construction sector [11] [25]. Ideally, the project manager ought to manage the process of project completion in the early phases of the construction cycle. Notably, the pre-project stage in most cases does not perform well in the construction industry. The criteria for project success are constantly enriched. There is therefore, need for a systematic critique of the existing literature to develop a framework for measuring construction success at both quantitative and qualitative levels [26].

Performance targets ought to be set to measure results in respect to construction projects. There is indeed a need to adopt collaborative working practices which have the propensity of contributing $30 \%$ to cost saving within five years [27]. This is also supported by Gardiner [3] who opined that the report has helped "to cut out the adversarial culture in construction and learn to collaborate-client, contractor, subcontractor, consultant-for the common good of the project." This affirms the need to ensure stakeholder participation in the road construction industry.

The construction industry has been marred with serious issues affecting project completion within the set budget, time and quality. There is an assumption that, after the conception stage, the project has been planned adequately. The main goal of forecasting is to plan for time, cost and resources. Stakeholder involvement or engagement in the project planning process should include a variety of actors with different roles and responsibilities to play in the planning phase of the project life cycle [10] [28]. Failure to adequately plan significantly diminishes the project's likelihood of effectively achieving its goals. Planning comprise analyzing, anticipating, scheduling, coordinating and controlling as well as information management. Methodical planning has exceptional benefits. These benefits comprise breaking down of multifaceted activities into manageable portions, and determining rational sequences of activities [28].

Project planning largely entails determining how to plan, developing the scope statement; selecting the planning team; identifying deliverables and creating the 
work breakdown structure. It also comprises categorizing the actions needed to achieve the envisaged deliverables [29] [30]. Additionally, processes such as planning for communications, determining roles and responsibilities, and other necessary meetings are advisable. Project planning require that project stakeholders develop a baseline plan involving; the description of resources; delivery methodologies and time schedule [31]. It is also noted that better planning of projects should analyze distinct phases of activity. This way, the outcome to each small increment can be evaluated separately [32].

Similarly, Heravi, Coffey and Trigunarsyah [8] examined the level of participatory project planning in enhancing project planning processes of building projects. The study targeted 200 companies whereby data was collected by use of questionnaires from the respondents who were directly involved in building residential houses and established that stakeholders were fully engaged in projects activities which contributed to better project performance and proposed improvement for further engagement of stakeholders. The study also established that the number and qualification of key personnel was identified and compiled into a project team during planning which positively influenced the project performance to a great extent. Further, Musau and Kirui [33] sought to investigate the extent to which project planning impacts the implementation of government projects in county governments, using Machakos County Government as an example. The study established that stakeholder participation in project planning has the most contribution to the implementation of government projects by the County Government of Machakos. The investigation presumed that key stakeholders should give their opinions on type and quantity of resources required for the project. Further, the study found that the stakeholders should have the necessary qualification and experience in developing a work breakdown structure for the project. In another study, Waweru [34] listed factors that would promote community participation in development projects, to include material benefits, development interest, development need, previous development experience, wanting to belong, to serve the community, project meets need and peer pressure. On the other hand, a study by Mandala [9] on the influence of stakeholder participation in project planning on completion of road construction projects in Kenya established that clients planned a budget for environmental and social impact studies and management during construction road projects in Bondo Sub County.

A study by Awini [13] sought to examine the challenges of the implementation of water and sanitation projects in Gushegu District in Ghana. Data collection techniques included interviews and administration of semi-structured questionnaires. The respondents were selected through purposive and convenience sampling techniques. The study sought to establish why beneficiaries were not quite often involved in the planning of projects. A total of 135 respondents (54\%) agreed that stakeholders are not always involved. Further, the results showed that $45.2 \%$ indicated that the stakeholders are neglected because of the 
misconception that beneficiaries are not capable of contributing meaningfully to the decision making of project. Other factors identified as impediments included organization requirements, time constraints or policies and the notion that planning does not directly concern beneficiaries. The study concluded that leaving out stakeholders would fuel some challenges during implementation. The study, however, failed to show the relationship and strength of the predictor variable, participatory project planning, hence the need for the current study.

Another study conducted by Mwanga and Kayunze [10] on the determinants of community participation in planning HIV and AIDS interventions under the national strategic framework in Mtwara region of Tanzania. The study adopted a cross-sectional research survey design, whereby, besides the 192 respondents randomly selected for questionnaire administration, twelve (12) focus groups were selected for qualitative data. For each of the 12 focus groups, about eight (8) community members were purposively selected, based on their being considered to be very knowledgeable. The study findings indicated that $81.8 \%$ did not participate in planning the interventions even though regression analysis was not carried hence the current study which sought to study participatory project planning and performance of urban road transport infrastructure projects.

Participatory project planning is equally linked to project budgeting and resource planning and allocation. Ochieng and Sakwa [12] studied the impact of participative resource mobilization in the implementation of community water projects on in Kisumu County of Kenya. Both descriptive and correlational research designs were adopted in this study. The target population comprised of 360 households from which a sample size of 189 was obtained through stratified sampling. The study relied mainly on the questionnaires and not interviews for collection of the data. The current study being a mixed method, it adopted both data collection tools to enhance results and more specifically for triangulation. The study showed that a statistical significant influence existed between participative resource mobilization and project implementation of the projects efficiently. The P-value of $t$-statistic for labor sourcing was 0.000 and that of finance mobilization was 0.003 , both below the P-value of 0.05 . The study recommended the importance of training the community members with relevant skills for implementing, operating and maintaining the projects. In another study by Onyango, Bwisa and Orwa [15], investigating factors influencing the implementation of public infrastructure projects in Kenya it was established that that participatory planning process would yield $24.5 \%$ of the variation in the implementation of the infrastructure projects.

The current study is grounded on the stakeholder theory. According to Freeman [18], the purpose of a project is to create optimum value for stakeholders. The theory identifies and models the groups that constitute stakeholders of a project. It also describes and recommends methods by which management can give due regard to the interests of those groups. The stakeholder theory makes a great contribution in the understanding of stakeholder involvement in fields 
such as project planning and organizational management [23]. Stakeholder theory focuses on the groups or individuals who affect or are affected by the organization's actions [18]. Stakeholders' theory presents a paradigm shift from where managers see stakeholders as bodies belonging to an organization for its benefit, to an approach of relationship networks for mutual benefit [23] [24]. Applying the theory to this study implies that stakeholders are part of urban road transport-infrastructure projects in Kenya and as such have a significant role in the processes and procedures that lead to the improvement of their completion. The theory is therefore relevant in the evaluation of urban roads transport infrastructure projects in the identification of the key stakeholders and their roles including their interests, power and influence [25].

In sum, the literature point to the concern over delays in project completion and the need to address these delays [5] [25]. These delays are occasioned by a myriad of factors including poor planning and not involving stakeholders in the planning process [28]. Part of the solution to these delays is pointed out as collaboration with stakeholders [27] [28] [31] [32]. This literature has examined several studies on stakeholder involvement [8] [10] [13] [15]. The role and importance of stakeholder participation in planning are already being noticed in projects undertaken by several Non-Governmental Organizations (NGOs), some projects funded by governments and multilateral donor agencies. Evidence of what works in stakeholder involvement has not been rigorously addressed in previous studies. These gaps contributed to the choice of this current study, which aims at examining the influence of stakeholder participation in project planning on the completion of urban road transport-infrastructure projects in Kenya.

\section{Methodology}

This study used a pragmatism paradigm, to guide a mixed research approach. This allowed the research to balance the weaknesses and strengths of two approaches; quantitative and qualitative. The aim of the study is to examine stakeholder participation in construction cycle and completion of urban road transport infrastructure-projects, which contain both social and scientific attributes. Mixed research allows the researcher to describe research phenomena in both social and natural settings through research processes [36]. The unit of analysis in this study was; Kenya Urban Roads Authority (KURA) project implementation teams' members, KURA project planners and directors, road contractor's project management teams, consultants construction supervision teams, representatives of Project Affected Persons, and complimentary service providers, making up a target population of 1593 participants. The sample size of the study was 309 participants. This was arrived at by utilizing [37] sample size determination research formula. Out of the 309 sampled respondents, 214 responded. This gave a response rate of $69.2 \%$, which is within the threshold of acceptance by [38]. The key informants interviewed include 17 representatives of PAPS and 8 
Complimentary service providers. This study obtained data from all 9 counties where KURA road projects were located through the use of a questionnaire. The questionnaire items were tested using a 5-point Likert scale where: $\mathrm{SA}=$ Strongly Agree (5), A = Agree (4), U = Uncertain (3), D = Disagree (2), SD = Strongly Disagree (1). The Likert scale items were designed as a series of questions that when combined measure a particular construct. An interview guide was issued to the key informants for triangulation. The study then employed both descriptive and inferential statistics for the data analysis. Pearson correlation coefficient analysis was conducted to identify the relationship between the independent variable (stakeholder participation in project planning) and the dependent variable (completion of urban road infrastructure projects). Further, to establish the strength of this relationship, simple linear regression analysis was performed.

\section{Results}

Data was sought to assess how stakeholder participation in project planning influence the completion of urban road transport infrastructure projects in Kenya.

\subsection{Overall Descriptive Analysis of Completion of Urban Roads Transport Infrastructure Projects}

Completion of urban roads transport infrastructure projects was considered in terms of project completion within time, project completion within cost, project completion within quality and stakeholder satisfaction. The composite mean and standard deviation of these factors are shown in Table 1.

Results in Table 1 indicate that the overall mean of completion of urban roads transport infrastructure projects was 4.10 while the composite standard deviation was 0.845 . The most dominant indicator was stakeholder satisfaction $(\mathrm{m}=$ 4.40). The opinions on this dimension were converging because the sub composite standard deviation was 0.758 , which is way below the composite standard deviation of 0.845 . This implies that the final product met stakeholder expectations though the views were spread; some were still dissatisfied as confirmed by the interviews.

The second best dimension was project being completed within specified quality $(\mathrm{M}=4.23)$ Most of the opinions on this dimension were diverging since the sub composite standard deviation was 0.837 which is below the composite

Table 1. Means and standard deviations of completion of urban roads transport infrastructure projects.

\begin{tabular}{ccc}
\hline Variable Dimension/Indicator & Sub-Composite Mean (M) & Sub-composite Std. Dev. \\
\hline Project Completion within Time & 3.72 & 0.812 \\
Project Completion within Cost & 4.04 & 0.974 \\
Project Completion within Specified Quality & 4.23 & 0.837 \\
Stakeholder Satisfaction & 4.40 & 0.758 \\
Composite Mean and standard deviation & $\mathbf{4 . 1 0}$ & $\mathbf{0 . 8 4 5}$ \\
\hline
\end{tabular}


standard deviation of 0.845 . The key informants revealed that road surface was smooth and comfortable for riding on, flooding does not occur during heavy rains and the road sections could easily be maintained in the future. The study however noted that quality tests after completing the project were not performed within the required specifications and that minimum repair works on the completed roads were not well done or adequately carried out.

On the dimension, project completion within cost indicated that this was not met with a mean of $(\mathrm{M}=4.04)$. Opinions on this dimension converged given the sub composite standard deviation was 0.974 which is above the composite standard deviation of 0.845 . The triangulation results validated this indicating that the completion within cost was not achieved because there was fluctuation of cost in fuel, materials used and the labor employed. The study also noted that there were no design omissions to contribute to additional cost. This third dimension therefore does adversely influence road performance.

Finally, project completion within time $(M=3.72)$ was not met. There was consistency of opinions on this dimension because the sub composite standard deviation was 0.812 below the composite standard deviation of 0.845 . The triangulation from key informants revealed that this is because land acquisition process for expansion of the road could have taken more time hence affecting the timelines or there was no clear dialogue and understanding between land sellers (community members) and the buyers (government) hence need to improve on this aspect. Others included delay in relocation of existing service lines (power, water, sewer, data, telephone); and, evacuation of informal settlement which might have taken quite longer duration of time. Although there may have not have been many variation orders in the construction phase, the ultimate project implementation was not on schedule. In overall, this dimension adversely affected completion time of the road project

In addition, responses from interviews of the key informants seems to support the quantitative findings. When asked about the phase of the project at which Land Commission officials are requested to commence the process of land acquisition for construction of urban roads projects, the land officials had some varied answers. Some said at the initiation stage when the project plans are being conceptualized, during mapping, some said after completion of designs, while most of them indicated the construction stage. One of the Land commission official said:

“...We were requested to commence the process of land acquisition for construction of roads projects after completion of surveying, mapping and after acquisition plans were drawn, and mostly after all persons to be affected are identified."... "We usually carry out this exercise at the construction stage, when we are sure of funding from the road authorizes, since funds are need for the payment of compensation..." (Land Commission Officials)

The commission officials further noted that there is need for proper resettle- 
ment of the land owners to avoid squatters; the land owners should be notified in time to avoid conflicts and hindrances to enable smooth project completion.

In conducting further interviews stakeholders, Kenya Power officials were requested to indicate their opinion on how the process of relocation of service lines affects roads projects construction. Majority of the officials indicated that it was just before commencement of the construction, when in a meeting with the key stakeholders that the agency is often instructed to relocate facilities without being given adequate time for preparation to undertake the activities. One of the Kenya Power official said:

“...I was requested to commence the process of removal and relocation of service lines to pave way for construction of outer ring road, after mobilization of the contractor"... "We are mostly asked to commence the process of removal and relocation of service lines for construction of roads immediately after the design is completed and after it has received approvals from all the concerned authorities. However, the request is usually not followed prompt payment of our relocation cost which intends leads further delays in project and also trigger some external socioeconomic cost the public".

When project beneficiaries, through representatives of resident associations asked to indicate their opinions on level of their satisfaction the completed roads projects. Most of the respondents indicated that the completed road projects enhanced the value of their land parcels. One of the affected person said,

"Good roads always come with a boost in the economic growth and that means I stand to benefit in the process as a business owner" Another affected person said, "As a business owner, transporting my products from the place of purchase to my business premises and also to customers will be enhanced and made easier. Also the traffic jams will be reduced and that means faster travel to and from any destination"

Additionally, most of the Matatu SACCO representative indicated that fares have dropped as a result of the completion of the roads;

"Yes, the fares dropped by almost $50 \%, \ldots$ vehicle maintenance costs reduced by almost $80 \%$ because the road is much smoother, ...the vehicle operating costs reduced drastically because the roads are in good condition ...the time taken to take people from one destination to another has reduced from one hour to almost $15 \mathrm{~min}$ during normal hours and $30 \mathrm{~min}$ during pick hours... time has been saved in that on highways the vehicles move faster unlike before the roads were expanded...”

\subsection{Overall Descriptive Analysis of Stakeholder Participation in Project Planning}

Participation in project planning was considered in terms of budgeting, resource planning, schedule of activities and scope planning. The composite mean and 
standard deviation of these factors are shown in Table 2.

The overall mean or composite mean of participation in project planning was 3.59 (Table 2). This therefore explains the importance and the level of influence it has on road construction project completion. The statements on budgeting yielded a mean of 2.94, which indicated that stakeholders' were not adequately involved in budgeting for road construction projects. The opinions on this indicator were inconsistent because the sub composite standard deviation was 0.975 above the composite standard deviation of 0.958 .

The statements on resource planning resulted to an average mean of 4.03, whereby the study findings showed that the project team was well qualified. The opinions on this indicator converged given the sub composite standard deviation was 0.924 below the composite standard deviation of 0.958 . The findings showed that stakeholders' involvement in sourcing for project's fund is important even though the road projects under KURA does not seem to rely on this. During resource planning, the client or consultant, on average, are committed to procuring the right sub-contractors for relocation of service lines and calculating minimum quantity of construction machinery, tools and equipment for delivering the required projects.

The statements on schedule of activities resulted to an average mean of 4.00. The opinions on this indicator converged since the sub composite standard deviation was 0.938 below the composite standard deviation of 0.958 . Triangulation results revealed that activities for land acquisition were planned during the scheduling stage thus the result.

The statements on scope planning generated an average mean of 3.43. The opinions on this indicator diverged given the sub composite standard deviation was 0.994 above the composite standard deviation of 0.958 . These results imply an average stakeholder influence on the performance of the road construction.

In addition to the analysis from the questionnaire, interviews were conducted key informants such as Kenya Power, National Land Commission and water service boards, for triangulation. The extracts are summarized in this section.

"In my opinion the process of relocation of power lines should commence and end during design stage and never during construction to avoid delay to the contractor"... 'It should commence immediately after the officer from

Table 2. Means and standard deviations of participation in project planning.

\begin{tabular}{ccc}
\hline Variable Dimension/Indicator & Sub-composite Mean (M) & Sub-composite mean Std. Dev. \\
\hline Budgeting & 2.94 & 0.975 \\
Resource planning & 4.03 & 0.924 \\
Schedule of activities & 4.00 & 0.938 \\
Scope planning & 3.41 & 0.994 \\
$\begin{array}{c}\text { Composite mean and } \\
\text { standard deviation }\end{array}$ & $\mathbf{3 . 5 9}$ & $\mathbf{0 . 9 5 8}$ \\
\hline
\end{tabular}


the county government or National government have given consent for the project to go on and also after the owner of the project has made all payment agreed by the two parties in full.." (Kenya Power official)

On when should the process of land acquisition be commenced, the land commission officials said it should be commenced immediately after surveying/ mapping then evaluation and compensation, after surveying the land and defining the location and agreement on compensation and immediately after valuation and compensation to settle everything to avoid interference thereafter.

Further, most of the water companies' officials said that process of relocation of water pipes is a major problem to construction of roads, since water and sewerage lines need to be out of the road construction sites, before anything happens and the contractor has to wait for it to happen. They particularly noted that the ill planned culture of limited integrated thinking has usually presented difficulties in the process since rushing will amount to doing wrong things, which will cause some challenges to construction of the project. One of the water company official said:

"Anything that will affect human activities either directly or indirectly should is major challenge. This is because a bad option will cause more damages than good. This end up creating conflict between the society and the project" ... "Yes, the process of water and sewage pipes relocation should be considered as a major problem to construction of roads because when they are doing the relocation it affects the people and is a health hazard to the people nearby especially when sewage pipes leak..."

When some project affected land owners were asked whether they were compensated on time, most of them said that they were not compensated on time. One of the affected person said,

"I was not compensated on time because it took me a lot of time to find the involved parties in the construction and up to now I have never been compensated". Another affected person said, "Yes I was compensated but not the amount I expected that could cover all my destroyed property and the compensation was not made on time it took a long time where I was forced to become a displaced person"

However, when some affected persons were asked to rate the process of land acquisition of the project, some of the projects affected persons rated it to be good, while most rated it to be poor. Some of the affected persons said;

"The process of land acquisition of the project was very poor because of the short notice given to us did not provide enough time to prepare for the loss of their property"... "All stakeholders were not involved... the project team just planned on their own and come up with the solution that favored them not caring about the land owners"... "The land acquisition process in this project is very poor because we are not involved in planning of the acquisi- 
tion and also the land officials are not professional enough on how they work on their project whereby they don't offer civil education to the affected parties..."

\subsection{Correlation between Participation in Project Planning and Completion of Urban Road Transport Infrastructure Project}

Analysis was carried out to establish the direction and magnitude of the relationship between the independent and dependent variables under investigation. This was in line with the second objective of this study, which was to establish how participation in project planning influences the completion of urban road transport infrastructure projects in Kenya. Participation in project planning was measured by budgeting, resource planning, schedule of activities and scope planning while completion of urban roads transport infrastructure projects was measured by project completion within time, project completion within cost, project completion within quality and stakeholder satisfaction. The results are presented in Table 3.

Table 3 indicates strong correlation between the completion of urban road transport infrastructure projects and budgeting $\mathrm{r}=0.783$ and $\mathrm{p}=0.001<0.05$ therefore implying that budgeting was significant. Resource planning had $\mathrm{r}=$ 0.598 and $\mathrm{p}=0.013<0.05$ which meant that it was significant. There was also a strong correlation between schedule of activities and completion of urban road transport infrastructure projects since $r=0.676$ and $p=0.009<0.05$ implying that it was significant while scope planning had $r=0.712$ and $p=0.014<0.05$ meaning that it was also significant. There was strong correlation between the completion of urban road transport infrastructure projects and participation in project planning $(\mathrm{r}=0.838)$ and the relationship was significant $(\mathrm{p}=0.011<$ $0.05)$.

\subsection{Regression Analysis of Influence of Participation in Project Planning on Completion of Urban Road Transport Infrastructure Projects}

Further linear regression analysis was conducted to establish the influence of participation in project planning on completion of urban road transport infrastructure projects in Kenya. Additionally, in testing its hypothesis data was

Table 3. Correlation between participation in project planning and completion of urban road transport infrastructure projects.

\begin{tabular}{cccccccc}
\hline & & Budgeting & $\begin{array}{c}\text { Resource } \\
\text { planning }\end{array}$ & $\begin{array}{c}\text { Schedule } \\
\text { of } \\
\text { activities }\end{array}$ & $\begin{array}{c}\text { Scope } \\
\text { planning }\end{array}$ & $\begin{array}{c}\text { Participation } \\
\text { in project } \\
\text { Planning }\end{array}$ \\
\hline $\begin{array}{c}\text { Completion of urban } \\
\text { road transport } \\
\text { infrastructure projects }\end{array}$ & $\begin{array}{c}\text { Pearson } \\
\text { Correlation }\end{array}$ & 0.783 & 0.598 & 0.676 & 0.712 & 0.838 \\
& Sig. (2-tailed) & 0.001 & 0.013 & 0.009 & 0.014 & 0.011 \\
& $\mathrm{n}$ & 214 & 214 & 214 & 214 & 214 \\
\hline
\end{tabular}


collected from the respondents on participation in project planning variables and then the composite index for each of the project planning variable indicators (budgeting, resource planning, schedule of activities and scope planning) was computed and used in the analysis. The results of the analysis are presented in Table 4.

Table 4 shows that $r=0.838$. This indicates that participation in project planning has a strong relationship with completion of urban road transport infrastructure projects in Kenya. $\mathrm{R}^{2}=0.703$ indicating that participation in project planning explains $70.3 \%$ of the variations in the completion of urban road transport infrastructure projects in Kenya.

The overall $\mathrm{F}$ statistics, $(\mathrm{F}=500.684, \mathrm{p}=0.000<0.05)$, indicated that there was a very statistical significant relationship between participation in project planning and completion of urban road transport infrastructure projects in Kenya. The null hypothesis was therefore rejected and it was concluded that participation in project planning significantly influences completion of urban road transport infrastructure projects in Kenya.

\section{Discussion of Findings}

The current study has established that stakeholder participation in project planning account for $70.3 \%$ ( $\mathrm{R}^{2}$ Squared) hence disapproving the findings of Awini

Table 4. Participation in project planning and completion of urban road transport infrastructure projects.

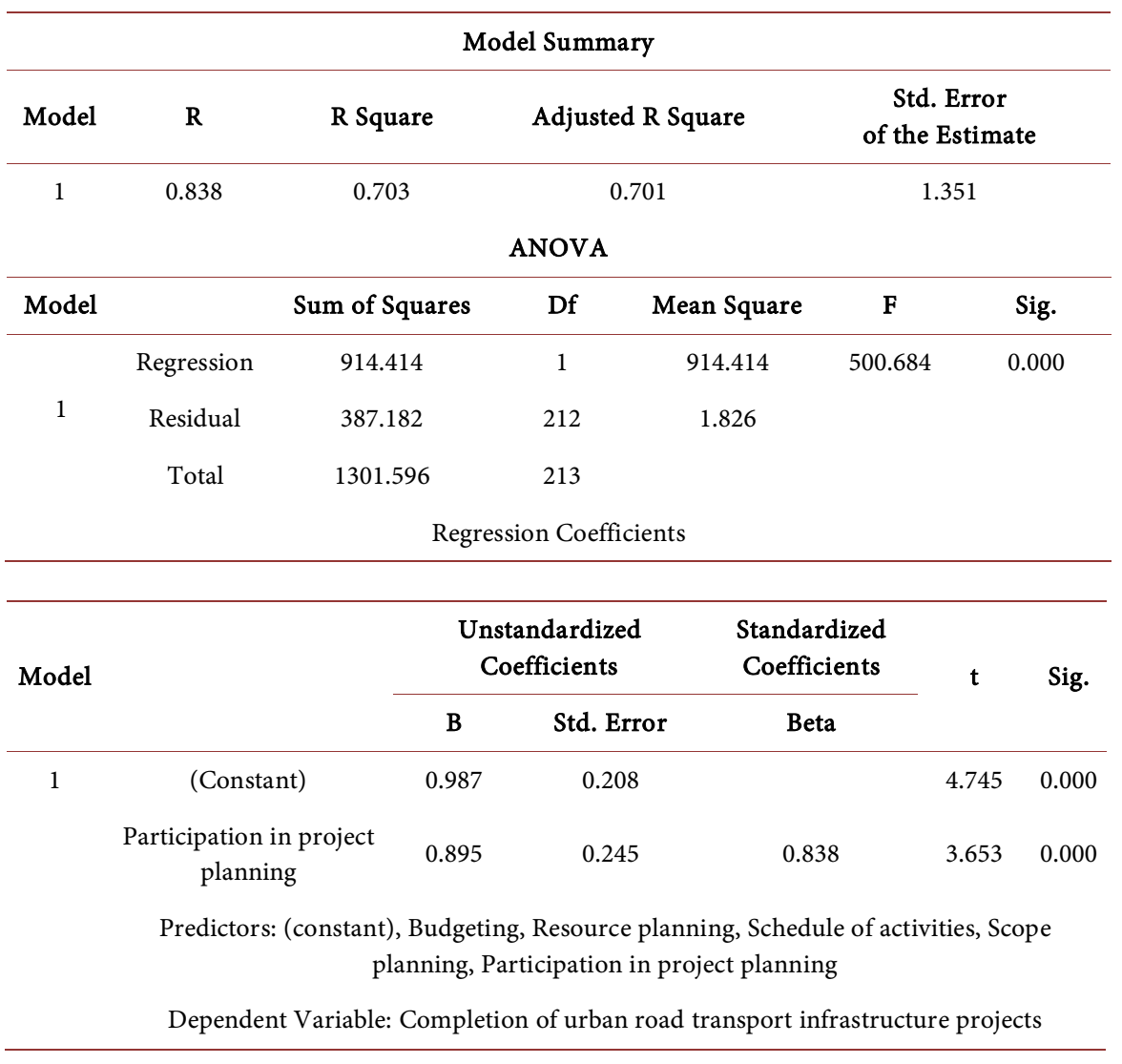


[13] who found that stakeholders are not always involved. The findings of this current study are further supported by the descriptive study by Mwanga and Kayunze [10], which indicated that $81.8 \%$ of stakeholders do not participate in planning the interventions.

The findings of the current study have empirically demonstrated in a unique way that budgeting is key in completion of urban roads transport infrastructure projects $(\mathrm{r}=0.783, \mathrm{p}=0.001<0.05)$, thus a positive and significance relationship. The findings are in agreement with Ochieng and Sakwa [12] whose study revealed a statistical significant influence between participative resource mobilization (budget) and efficiency in project implementation.

The findings in the current study supports the findings by Bwisa and Orwa [15], who failed to accept the null hypothesis that participatory planning processes do not influence implementation of public infrastructure projects. After the analysis the result indicated that participatory planning process would yield $24.5 \%$ of the variation in the implementation of the infrastructure projects, which was quite below the results of the current study with an impressive value of $70.3 \%$.

In sum, Pinto, and Prescott, [39] who did a stepwise regression on the critical success factors at each of the four stages in the project life cycle, vindicate the results of this study. The results indicated that the relative importance of several of the critical factors change significantly based on life cycle stages. This implies that dealing with each stage at a time will be beneficial.

\section{Conclusions}

Overall, the study concluded that participation in project planning significantly influences completion of urban road transport-infrastructure projects in Kenya. More specifically, the following conclusions are made:

1) That all the four indicators were significant with budgeting having the highest effect on completion of urban road transport infrastructure projects followed by scope planning then schedule of activities and finally resource planning.

2) The stakeholders need to be sensitized to be involved in defining the scope of work, not taking into consideration the request by the community request to have adequate pedestrian walkways, zebra crossings and footbridges and scope of relocation of service lines being determined by relevant government agency based on information provided by stakeholders.

3) There is need for key stakeholders to have the necessary qualification and experience in developing a work breakdown structure for the project.

\section{Recommendations}

Based on the findings of this study and the conclusions thereof, this study makes the following recommendations:

1) There is a need to increase training and awareness on participation in 
project planning among the project managers, contractors and consulting engineers in road construction. This is to enable them work together with all stakeholders to enhance project quality and acceptability.

2) There is also a need for key stakeholders to have the necessary qualification and experience in developing a work breakdown structure for the project. This would ensure that the stakeholders have the skills and knowledge as well as undergo in-service training to keep them updated in project planning and implementation matters.

3) There is also a need to include all stakeholders in project planning in the project cycle as each play an active role since they are the consumers of the project for the sake of sustainability. Cooperation of stakeholders should also be encouraged.

4) There is critical need to develop a guiding policy document detailing the importance of stakeholder participation in road construction life cycle in order to curb any future misgivings in implementation of these important socio-economic projects.

\section{Acknowledgements}

I wish to acknowledge the University of Nairobi Supervisors led by Prof. Dorothy Ndunge Kyalo, Dr. John Mbugua, and Dr. Angeline Mulwa. I also thank KURA project implementation teams' members; KURA project planners and directors; road contractor's project management teams; consultants construction supervision teams; representatives of PAPs, and complimentary service providers; All those who have not been mentioned but played a role in my academic pursuit are most appreciated.

\section{Conflicts of Interest}

The authors declare no conflicts of interest regarding the publication of this paper.

\section{References}

[1] Rubaba, A., Federico, B.A., Claudia, B., Richard, D., John, N. and Jason, R. (2015) Highways to Success or Byways to Waste: Estimating the Economic Benefits of Roads in Africa. Africa Development Forum. World Bank and Agence Françaisede Développement, Washington DC.

https://openknowledge.worldbank.org/handle/10986/22551

[2] Lindborg, H.J. (2013) Stake Your Ground: Unearthing the Origins of Stakeholder Management. Quality Progress, 2, 1-3.

[3] Gardiner, J. (2014) Latham's Report: Did It Change Us? https://www.building.co.uk/focus/lathams-report-did-it-change-us/5069333.article

[4] Khan, A.Z., Skibniewski, M. and Cable, J.H. (2018) The Project Stakeholder Management and Engagement Strategy Spectrum: An Empirical Exploration. Originally Presented at the 2018 University of Maryland Project Management Symposium, May 2018, Republished as a Second Edition in the PM World Journal, Vol. VIII, Issue III (April). 
https://pmworldlibrary.net/wp-content/uploads/2019/04/pmwj80-Apr2019-Khan-S kibniewski-Cable-Project-Stakeholder-Management-Strategy-Spectrum.pdf

[5] Republic of Kenya (2018) Senate Bills 2018. Kenya Gazette Supplement No. 17 (Senate Bills No. 4).

http://kenyalaw.org/kl/fileadmin/pdfdownloads/bills/2018/PublicParticipationBill_ 2018.pdf

[6] Williams, T. (1999) Allocation of Contingency in Activity Duration Networks. Construction Management and Economics, 17, 441-447. https://doi.org/10.1080/014461999371367

[7] Cheng, H., Shimiao, J. and Danfeng, Z. (2010) Risk Identification of Public Infrastructure Projects Based on VFPE. 2010 The 2nd International Conference on Computer and Automation Engineering (ICCAE), Singapore, 2010, 173-176.

[8] Heravi, A., Coffey, V. and Trigunarsyah, B. (2015) Evaluating the Level of Stakeholder Involvement during the Project Design Processes of Building Projects. International Journal of Project Management, 33, 985-997. https://doi.org/10.1016/j.ijproman.2014.12.007

[9] Mandala, E. (2018) Influence of Stakeholders' Involvement in Project Management on the Completion of Road Construction Projects in Kenya: A Case of Bondo Sub County, Siaya County. Unpublished Maters Thesis of the University of Nairobi.

[10] Mwanga, J.E. and Kayunze, K.A. (2016) Determinants of Community Participation in Planning HIV and AIDS Interventions under National Multisectoral Strategic Framework in Mtwara Region, Tanzania. International Journal of Ebola, AIDS, HIV and Infectious Diseases and Immunity, 2, 29-46.

[11] Ndegwa, M.N., Mavole, J.N. and Muhingi, W.N. (2017) Influence of Public Participation on Successful Implementation of Public Health Projects in Nyeri South Sub-County, Nyeri County, Kenya. International Journal of Social and Development Concerns, 1, Article 7/12.

[12] Ochieng, F.O. and Sakwa, M. (2018) Impact of Participatory Resource Mobilization in the Implementation of Community Water Projects on the Well-Being of Beneficiaries' Households in Kisumu County. The Strategic Journal of Business Change, 5, 1709-1720.

[13] Awini, R.A. (2018) Challenges of the Implementation of Water and Sanitation Projects in Gushegu District. Texila International Journal of Management, 4. https://doi.org/10.21522/TIJMG.2015.04.02.Art009

[14] Burgess, T. and Stern, M. (2013) Efficient Methods of Managing Project Teams. $2^{\text {nd }}$ Edition, Harper, Switzerland.

[15] Onyango, L.B., Bwisa, H. and Orwa, G. (2017) Critical Factors Influencing the Implementation of Public Infrastructure Projects in Kenya: A Case of Thika Sub-County, Kiambu County Kenya. International Journal of Scientific and Research Publications, 7, 200-211.

[16] Osman, M.A. and Kimutai, G. (2019) Critical Success Factors in the Implementation of Road Projects in Wajir County, Kenya. International Academic Journal of Information Sciences and Project Management, 3, 73-104.

[17] Aje, I. (2012) The Impact of Contractors' Prequalification on Construction Project Delivery in Nigeria. Engineering, Construction and Architectural Management, 19, 159-172. https://doi.org/10.1108/09699981211206098

[18] Freeman, R.E. (1984) Strategic Management: A Stakeholder Approach. Pitman Press, Boston, 46. 
[19] Walters, G. (2011) The Implementation of a Stakeholder Management Strategy during Stadium Development: A Case Study of Arsenal Football Club and the Emirates Stadium. Managing Leisure, 16, 49-64. https://doi.org/10.1080/13606719.2011.532600

[20] Walters, G. and Tacon, R. (2010) Corporate Social Responsibility in Sport: Stakeholder Management in the UK Football Industry. Journal of Management and Organization, 16, 566-586. https://doi.org/10.1017/S1833367200001942

[21] Peachey, J. and Bruening, J. (2010) An Examination of Environmental Forces Driving Change and Stakeholder Responses in a Football Championship Subdivision Athletic Department. Sport Management Review, 14, 202-219. https://doi.org/10.1016/j.smr.2010.09.002

[22] Mitchell, R., Agle, B. and Wood, D. (1997) Toward a Theory of Stakeholder Identification and Salience: Defining the Principle of Who and What Really Counts. Academy of Management Review, 22, 853-886. https://doi.org/10.5465/amr.1997.9711022105

[23] Miragaia, D., Ferreira, J. and Carreira, A. (2011) Identification and Prioritization of Stakeholders to Support Strategic Decision-Making in Sports Organizations-A Case Study. Journal of Sport Management.

[24] Nguyen, S.N. and Menzies, J. (2010) Event Effectiveness: Analysing the Perceptions of Key Stakeholders of the Lexmark Indy 300/Champ Car Event, Gold Coast. International Journal of Sport Management and Marketing, 8, 106-130. https://doi.org/10.1504/IJSMM.2010.033952

[25] Love, P.E., Edwards, D.J. and Irani, Z. (2012) Moving beyond Optimism Bias and Strategic Misrepresentation: An Explanation for Social Infrastructure Project Cost Overruns. IEEE Transactions on Engineering Management, 59, 560-571. https://doi.org/10.1109/TEM.2011.2163628

[26] Glaister, Allport, Brown and Travers (2010) Success and Failure in Urban Transport Infrastructure Projects. KPMG International.

[27] Latham, M. (1994) Constructing the Team: Final Report of the Government/Industry. Review of Procurement and Contractual Arrangements in the UK Construction Industry. HMSO ISBN011752994x.

[28] Kerote, O.A. (2007) The Role of the Local Community in the Management of Constituency Development Funds in Sabatia Constituency in Vihiga. A Research Project, University of Nairobi, Kenya.

[29] Chandrasekara, C. and Herath, P. (2019) Setting Up a Team Project. In: Hands-On Azure Boards, Apress, Berkeley, CA.

[30] Rosario, J.G. (2000) On the Leading Edge: Critical Success Factors in ERP Implementation Projects. Business World, 15-29.

[31] Ling, F.Y.Y. and Ma, Y. (2014) Effect of Competency and Communication on Project Outcomes in Cities in China. Habitat International, 44, 324-331. https://doi.org/10.1016/j.habitatint.2014.07.002

[32] Kulkarni, R., Bargstädt, H.J. and Huckfeldt, J. (2004) Differential Role of Alliance Leadership at Various Phases on Projects in Cross-Cultural Milieu. Proceedings of the IPMA World Congress on Project Management, Budapest, 19-20 June 2004.

[33] Musau, P.M. and Kirui, C. (2018) Project Management Practices and Implementation of Government Projects in Kenya, Case of Machakos County Government. International Academic Journal of Information Sciences and Project Management, 3, 58-79. 
[34] Waweru, R. (2015) Factors Which Promote Community Participation in the Community Driven Development Approach. International Journal of Humanities and Social Science Studies, 1, 13-18.

[35] Gagné, M. and Deci, E.L. (2005) Self-Determination Theory and Work Motivation. Journal of Organizational Behaviour, 26, 331-362. https://doi.org/10.1002/job.322

[36] Sarantakos, S. (2010) Social Research. 2nd Edition, MacMillan Educational, Melbourne.

[37] Yamane, T. (1967) Statistics: An Introductory Analysis. Harper and Row, New York.

[38] Bryman, A. and Bell, E. (2015) Business Research Methods. Oxford University Press, Oxford.

[39] Pinto, J. and Prescott, J.E. (1988) Variations in Critical Success Factors over the Stages in the Project Life Cycle. Journal of Management, 14, 5-18.

https://doi.org/10.1177/014920638801400102 